\title{
THE IMPACT OF LEADER BEHAVIOUR ON TRUST IN MANAGEMENT AND CO-WORKERS
}

\author{
DEANNE N. DEN HARTOG \\ Organizational Psychology, Faculty of Economics \\ Erasmus Universiteit Rotterdam \\ MICHAELA C. SHIPPERS \\ Work and Organizational Psychology \\ Vrije Universiteit Amsterdam \\ PAUL L. KOOPMAN \\ Work and Organizational Psychology \\ Vrije Universiteit Amsterdam
}

\begin{abstract}
Within organizations, trust is essential for cooperation. One important form of trust is employees' generalizing of trust in management and co-workers. Leaders may have an important role in enhancing such trust. Previous studies have linked transformational leadership with employees' trust in their leader. In this study, we test whether such leadership is also related to trust in generalized others (management and co-workers). As expected, trust in the leader and management were highly positively related to transformational and less so to transactional. The same pattern was found for trust in colleagues, although these relationships were less strong.
\end{abstract}

\section{OPSOMMING}

Vertroue is onontbeerlik vir samewerking in organisasies. Een vorm van vertroue wat belangrik is, is werknemers se veralgemening van vertroue in bestuur en medewerkers. Bestuur mag ' $n$ belangrike rol hê om dié vertroue te versterk. Vorige studies het transformasieleierskap gekoppel aan werknemers se vertroue in hul bestuurder. In hierdie studie word getoets of transformasieleierskap ' $n$ verband toon met die veralgemening van vertroue (bestuur en medewerkers). Soos verwag, het vertroue in die leier en vertroue in medewerkers ' $n$ hoogs positiewe verband getoon met transformasieleierskap. Dieselfde patroon het voorgekom by vertroue in medewerkers, alhoewel die verhouding minder sterk is.

Trust has been described as an important feature in both interpersonal relationships and larger collectivities such as organizations or societies. Trust is seen as an important basis for cooperation. For instance, Gambetta (1988, p. 235) holds that "trust uncovers dormant preferences for cooperation tucked under the seemingly safer blankets of defensive-aggressive revealed preferences". Also, Williams (1988) relates trust to a "motivation to cooperate" and states that "cooperation requires trust in the sense that the dependent parties need some degree of assurance that the other, non-dependent parties will not defect" (p. 8). Others such as Mayer, Davis and Schoorman (1995) emphasize vulnerability, that is the willingness of a party to be vulnerable to the actions of another party, as an important part of trust. They propose a model of antecedents and outcomes of organizational trust, integrating research from multiple disciplines and differentiating trust from similar constructs such as cooperation, confidence and predictability.

Different definitions of trust have been proposed from the context of individual expectations, interpersonal relationships, economic exchanges, social structures, and ethical principles (see Hosmer, 1995). For example, Creed and Miles (1996) describe trust as both the specific expectation that another's actions will be beneficial rather than detrimental and as the generalized ability to take for granted, or to take "under trust", a wide array of features in the social order. This definition incorporates both individual expectations and social structures. Cook and Wall (1980) hold that trust between individuals and groups within an organization is a highly important ingredient in the long-term stability of the organization. They define trust as the extent to which one is willing to ascribe good intentions to and have confidence in the words and actions of other people. They view trust as a dimension of interpersonal relationships. The current study focuses on such interpersonal trust within organizations and especially on the relationship between leadership and trust.

Requests for copies should be addressed to: DN Den Hartog, Department of Organisational Psychology, Faculty of Economics, Erasmus Universiteit,

Rotterdam. E-mail: D.N.den.Hartog@fppl.psy.vu.nl
It extends previous research by looking not only at trust in the focal leader (a specific other), but also at trust in management and co-workers (generalized others) as possible correlates of leadership.

Transformational and transactional leader

Since its introduction over 20 years ago, transformational or charismatic leadership has been strongly emphasized in the management literature (e.g. Bass, 1985, 1997; Den Hartog et al, 1999; Den Hartog \& Koopman, 2001; House, 1996). Such transformational leaders articulate a realistic vision of the future that can be shared, stimulate subordinates intellectually, and pay attention to the differences among the subordinates (Bass, 1985; Den Hartog, Van Muijen \& Koopman, 1997; Yammarino \& Bass, 1990). Many hold that the presentation of an ideological vision that describes a better future and is congruent with the dearly held values of followers is central to this type of leadership. By articulating such a vision, transformational leaders may instill pride, gain respect and trust, and increase the sense of optimism and hope (Shamir, House \& Arthur, 1993). The leader's personal example serves as a model of the kind of behavior required to attain the vision (House \& Podsakoff, 1994). Transformational leaders also intellectually stimulate followers, providing them with a flow of challenging, new ideas that should stimulate them into rethinking old ways of doing things (Bass, 1985). Furthermore, while a leader's charisma may attract subordinates to a vision or mission, the leader's individualized consideration also significantly contributes to individual subordinates' achieving their fullest potential (Bass, 1985). In this vein, House (1977) also emphasizes the importance of confidence building and expressing confidence in followers.

Bass (1985) holds that transformational leaders broaden and elevate followers' interests, generate awareness and acceptance among the followers of the purposes and mission of the group, and motivate followers to go beyond their self-interests for the good of the group. According to Bass (1985) the transformation of followers can be achieved by raising their awareness of the 
importance and value of desired outcomes, getting followers to transcend their own self-interests and altering or expanding followers' needs. Tichy and Devanna (1990) highlight the transforming effect these leaders can have on organizations as well as on individuals. By defining the need for change, creating new visions, and mobilizing commitment to these visions, leaders can ultimately transform organizations.

Transformational or charismatic leadership is usually contrasted with transactional leadership. Transactional leadership defines leader-follower relationships as based on implicit and/or explicit cost-benefit exchanges. A transactional leader recognizes what followers want to get from their work and tries to see that they get what they desire if their performance warrants it (Bass, 1985). In measuring transactional leadership, two types of transactional leadership are often distinguished: contingent rewarding and management-by-exception (Bass, 1985). A distinction will also be made between these two types of transactional leadership in the study presented below.

Contingent rewarding entails a positive exchange in which followers are rewarded for expending the necessary effort or attaining specified performance levels. The leader specifies performance criteria, and promises and gives rewards if performance meets the agreed upon standards. The leader also creates conditions under which the employee can indeed perform well, for example gives feedback and ensures availability of resources. Research shows that contingent rewarding positively affects subordinate performance and satisfaction (e.g. Podsakoff, Todor \& Skov, 1982).

Management-by-exception (MBE) entails a focus on corrective action and (preventing) mistakes and irregularities in follower performance. A leader intervenes when things go wrong or standards are not met (Bass, 1985). Although MBE is commonly referred to as "transactional" it is less exchange based than contingent rewarding. It is perhaps best described as performance monitoring. In their model, Bass and associates distinguish between two forms of MBE, namely active and passive (e.g. Bass $\&$ Avolio, 1990). The difference is that in the active form the leader searches for deviations and takes preventive action, whereas in the passive form the leader waits for problems to materialize (Hater \& Bass, 1988). However, others hold that (at least in the way passive MBE is measured) it seems to have more in common with so-called passive or laissez-faire leadership (e.g. Den Hartog et al, 1997). Passive leaders avoid taking action or making decisions (e.g. Bass, 1985, 1997). Laissez-faire leadership and passive MBE correlate negatively with the more active leadership styles and can be combined into a single passive leadership factor (Den Hartog et al, 1997). Passive leadership was not measured in this study.

\section{Outcomes of leadership}

In general, transformational leadership is expected and found to lead to more positive effects on subordinates than transactional leadership. Fiol, Harris and House (1999) note that theories emphasizing transformational/charismatic leadership have been subjected to more than 100 empirical tests. Collectively, the findings of these studies demonstrate that transformational or charismatic leaders have positive effects on their organizations and followers, with effect sizes ranging from 0,35 to 0,50 for organizational performance effects, and from 0,40 to 0,80 for effects on follower satisfaction, commitment, and organizational identification (Fiol et al, 1999). Two recent meta-analytical studies of the literature support this conclusion (Fuller, Patterson, Hester \& Springer, 1996; Lowe, Kroek \& Sivasubramaniam, 1996). Lowe et al. (1996) find a 0,81 corrected correlation between charisma and subordinates' ratings of leader effectiveness and a 0,35 mean corrected correlation between such leadership and independent ratings of leader effectiveness in their meta-analytic review of the literature. Although many studies are cross-sectional in nature, several longitudinal (e.g. Howell \& Avolio, 1993) and experimental (e.g. Kirkpatrick \&
Locke, 1996) studies also support the conclusions reported above. Furthermore, there is evidence that both the positive endorsement and the positive effects of this type of leadership are found in a wide range of countries (Bass, 1997; Den Hartog et al., 1999). The current study focuses on the relation between leader behavior and trust in co-workers and management.

\section{Interpersonal trust}

Although much of the literature on interpersonal trust focuses on trust in romantic or personal relationships, several authors also describe the interpersonal nature of trust within organizations. Butler and Cantrell (1984), for instance, combined trust as a condition for cooperation with inequality in position and proposed five specific components of trust (or characteristics of the people involved). It was expected that the degree of each would differ depending on the position (superior or subordinate) of the person. The components they proposed are: integrity, competence, consistency, loyalty, and openness. Integrity refers to the trusted party's reputation for honesty and truthfulness. Competence refers to the technical knowledge and interpersonal skills needed for job performance. Consistency refers to reliability, predictability, and good judgment in handling situations. Butler and Cantrell (1984) describe loyalty as benevolence or the willingness to protect, support, and encourage others. Butler (1991) later refined the dimension of loyalty by changing from a proposed attitude of general benevolence to an implicit promise from one party not to cause harm to the other. Openness refers to mental accessibility or the willingness to share ideas and information with others freely (see also Hosmer, 1995).

Lewicki and Bunker (1996) propose a developmental model of three sequentially linked types of trust in professional relationships, namely calculus-based trust, knowledge-based trust, and identification-based trust. Calculus-based trust "is based on assuring consistency of behavior; that is, individuals will do what they say because they fear the consequences of not doing what they say" (Lewicki \& Bunker, 1996, p. 119). Trust is sustained to the extent that the possible punishment is both clear and likely to occur when trust is violated. The second form is knowledge-based trust. "This form of trust is grounded in the other's predictability - knowing the other sufficiently well so that the other's behavior is anticipatable" (Lewicki \& Bunker, 1996, p. 121). In this stage, trust relies on information rather than deterrence. Over time, a generalized expectancy about the predictability and trustworthiness of the other party's behavior develops. Regular communication and "courtship" are key processes in developing knowledge-based trust (Shapiro, Sheppard \& Cheraskin, 1992). Regular communication ensures a constant exchange of information about wants, needs and expectancies, and ensures that parties do not "lose touch". "Courtship" is behavior that is specifically aimed at relationship development and learning more about the other party, again contributing to predictability. The third type of trust Lewicki and Bunker describe, namely identification-based trust, is based on identification with the other's desires and intentions. At this level, "trust exists because the parties effectively understand and appreciate the other's wants; this mutual understanding is developed to the point where they can effectively act for the other" (1996, p. 122). Increased identification literally enables one party to think, feel and respond like the other party. People may empathize strongly with the other party and incorporate ideas and ways of responding of this other party into their own identity (i.e. their needs, preferences, thoughts, and behavior patterns) as a collective identity develops.

\section{Trust in the leader}

Both transactional and transformational leader behaviours can enhance the development of trust in the leader. Management-byexception would probably lead primarily to calculus-based trust through the emphasis on monitoring and controlling whether subordinates perform as expected (performance monitoring). For instance, Bass (1985) states that negative feedback "can provide 
the novice subordinate with needed advice on what not to do" (p. 135). Going beyond calculus-based trust, contingent rewarding and individualized consideration should increase knowledge-based trust. Consistently practising contingent reward involves keeping promises that were made (e.g. regarding extra pay or a promotion for work well done). At a higher level, contingent reward may also involve non-material recognition of subordinates' performance. In time, contingent reward should increase knowledge-based trust, as subordinates will increasingly rely upon the leader to reward them for their efforts as promised. Individualized consideration involves treating each subordinate differently according to their needs and capabilities, and giving them personal attention (Bass, 1985). This can take different forms, for instance, appreciating a job well done (much like higher levels of contingent reward), advising subordinates what to do, and providing developmental feedback. Individualized consideration obviously addresses the relationship development needed for knowledge-based trust and it ensures the exchange of information on expectancies, needs and wants, another important element of this type of trust. Finally, according to Lewicki and Bunker (1996) many of the activities that increase the other forms of trust also serve to develop identificationbased trust. They also name four types of activities that work more specifically to increase identification-based trust. They are: developing a collective identity; co-location (working in the same building/neighborhood); creating joint products or goals; and committing to commonly shared values. Articulating an attractive vision and having shared goals to strive for, committing to shared values, and developing a sense of collective identity are all important components of transformational leader behavior and also seem likely to increase identification-based trust. Several theories of transformational leadership (e.g. Shamir et al, 1993) emphasize the importance of developing a collective identity and the importance of followers' identification with certain values and the collective identity. Personal and social identification as well as value internalization play a role in this leadership process (Den Hartog, 1997). These processes should also be linked to identification-based trust.

Trust in the focal leader has been studied in previous research. Podsakoff, MacKenzie, Moorman and Fetter (1990) examined subordinates' trust in the leader as a mediating variable in the relationship between transformational leadership and so-called organizational citizenship behaviors (OCBs). OCBs describe employees' extra-role behavior, including showing behavior such as civic virtue, courtesy and altruism. They show that trust does indeed mediate the relationship between transformational leadership and OCBs. More specifically, they show that transformational leadership has a direct effect on both employee trust and satisfaction (but not on OCBs), and that trust (but not satisfaction) has a direct effect on OCBs. The operationalization of trust in the leader (6 items) used by Podsakoff et al (1990) incorporates three items referring to perceived fairness and integrity of the leader, two items regarding loyalty towards the leader, and one item which asks whether the follower would support the leader in almost any emergency. In their study these different aspects of trust are combined in a single scale. In the present study, we include one aspect of trust in a leader, namely followers' faith in their leader and confidence in the leader's ability to overcome problems. In the remainder of this paper we will refer to such follower's faith and confidence in the leader as "trust in the leader". Transformational leadership is expected to correlate higher with trust in the focal leader than with transactional leadership. However, a certain degree of trust also appears important for transactional leadership, especially for contingent reward. Promises of rewards for performance are only likely to be effective when employees trust they will receive what was promised. Thus, a lower but positive relationship with faith in the leader is expected for contingent reward.

\section{Trust in management and co-workers}

Besides developing trust in the focal leader-follower relationship, employees can also develop more generalized trust in management and trust in colleagues or co-workers. Hosmer (1995) states that the literature regarding trust in management has focused mostly on (the role of personal characteristics in) superior-subordinate relationships, whereas the literature on distrust in management has included generalized others.

It follows from the various possible definitions that besides trust in specific others, trust in generalized others can be important in the development and maintenance of cooperative attitudes towards those parties and the organization as a whole. Trusting management or co-workers, for instance, is likely to influence employees' behavior towards these groups and the amount of effort they are willing to expend on their behalf. The interpersonal trust scales as developed by Cook and Wall (1980) were used to measure trust in management and co-workers. The scales refer to two aspects of trust, namely having confidence in management/colleagues and having faith in management/ colleagues. Clegg and Wall (1981) found that trust in management declines as one moves down the management, supervisory, white collar and blue collar hierarchy. Given its emphasis on values and processes of internalization, transformational leadership is expected to foster a cooperative and trusting attitude towards both management and co-workers. Furthermore, by increasing team spirit and the idea that the group works together as a collectivity, transformational leaders could affect trust in coworkers. Also, trusting one's own leader, feeling treated fairly, and the idea of pursuing a common organizational goal are expected to foster a more generalized sense of trust in management. The relationship between transformational leadership and generalized trust in management and colleagues is expected to be stronger than the relationship between transactional leadership and these types of trust. Trust in the leader is also expected to be related to trust in management.

\section{METHOD}

\section{Sample and procedure}

The sample in this study consisted of 330 employees of two organisations. The first was a utilities firm, the second an organization in the entertainment industry. Respondents received questionnaires and covering letters in person at work and could send or hand in the questionnaire after completion. Researchers were available to answer questions. In total, 212 people returned (usable) questionnaires. The response was approximately $80 \%$ in the public utility firm $(n=145)$ and $45 \%$ in the entertainment company $(\mathrm{n}=67) .82 \%$ of the respondents were male and $7,5 \%$ had a managerial position.

\section{Measuring instrument}

The items used in the leadership scales were chosen from a larger pool of items in the Inspirational Leadership in Organizations (ILO) questionnaire used in previous research (Den Hartog, 1997). The ILO is based on and also adds to several questionnaires, namely the MLQ-8Y (Bass \& Avolio, 1990), the Value-Based Leadership Questionnaire (House, Delbecq \& Taris, 1998) and the questionnaire used by Podsakoff et al (1990). For a description of the development of the ILO and the complete pool of items, see Den Hartog (1997). In the current study, only part of the ILO was used (as described below).

Transformational leadership. Five scales measuring different dimensions of transformational leadership were included (charisma, vision, intellectual stimulation, individualized consideration and demonstrating trust in others). A 5-item scale tapping charisma was used. A sample item is "projects a powerful, magnetic, and dynamic presence" (Cronbach $\alpha 0,87$ ). A 5-item scale referring to vision was used. A sample item is "articulates a vision of future opportunities" (Cronbach $\alpha 0,88$ ). 
A 7-item scale referring to intellectual stimulation was used (Cronbach $\alpha 0,86$ ). A sample item is "challenges me to think about old problems in new ways". A 5-item scale tapping individualized consideration was used (Cronbach $\alpha$ 0,85). Demonstrating trust in others was a 3-item scale (Cronbach $\alpha$ $0,80)$. All leadership items were measured on a 5-point scale.

Transactional leadership. Seven items were used to assess performance monitoring (or management-by-exception). Examples are "would indicate disapproval if I performed at a low level", "points it out to me when my work is not up to par" and "focuses attention on errors I make". Cronbach $\alpha$ is 0,88 . Four items were used to assess contingent reward behavior. A sample item is "tells me what to do to be rewarded for my efforts". Cronbach $\alpha$ is 0,82 .

Trust in the leader. Two items were used to assess subordinates' faith and confidence in their focal leader, namely "I have complete confidence in him/her" and "I am ready to trust him/her to overcome any obstacle". Cronbach $\alpha$ is 0,82 . Trust in the leader was measured on a 5-point scale.
Trust in management and co-workers. The interpersonal trust scales used in this study were back-translated from Cook and Wall (1980). Six items assess trust in colleagues $(\alpha=0,85)$ and six assess trust in management $(\alpha=0,87)$ on a six-point scale. Sample items are "One can trust management's ability to make the right decisions regarding the future of our organization" and "I can rely on my co-workers to help me if necessary". These items were measured on a 6-point scale.

\section{RESULTS}

Table 1 presents the scale means and intercorrelations between the scales used in this study. Consistent with previous studies, transformational leadership behaviors are found to be highly correlated. As table 1 shows, trust in the leader is significantly positively related to trust in management $(0,55)$ and to trust in colleagues $(0,27)$. As one would expect, the latter relationship is less strong. In addition, table 1 shows that all five scales tapping transformational leadership are significantly positively related to the three forms of trust. The transactional scales are also

\section{TABLE 1}

MEANS AND INTERCORRELATIONS OF THE SCALES

\begin{tabular}{|l|l|l|l|l|l|l|l|l|l|l|l|}
\hline & Mean & $\mathbf{1}$ & $\mathbf{2}$ & $\mathbf{3}$ & $\mathbf{4}$ & $\mathbf{5}$ & $\mathbf{6}$ & $\mathbf{7}$ & $\mathbf{8}$ & $\mathbf{9}$ & $\mathbf{1 0}$ \\
\hline 1. Cont. Reward & 1,65 & 1,00 & & & & & & & & \\
\hline 2. Perf. Monitoring & 2,89 & $0,34^{* *}$ & 1,00 & & & & & & & \\
\hline 3. Intell. Stim & 2,54 & $0,56^{* *}$ & $0,45^{* *}$ & 1,00 & & & & & & & \\
\hline 4. Demon. Trust & 3,36 & $0,35^{* *}$ & $0,20^{* *}$ & $0,59^{* *}$ & 1,00 & & & & & & \\
\hline 5. Ind. Consider & 3,12 & $0,46^{* *}$ & $0,35^{* *}$ & $0,66^{* *}$ & $0,76^{* *}$ & 1,00 & & & & & \\
\hline 6. Charisma & 2,73 & $0,47^{* *}$ & $0,46^{* *}$ & $0,61^{* *}$ & $0,55^{* *}$ & $0,72^{* *}$ & 1,00 & & & & \\
\hline 7. Vision & 2,47 & $0,46^{* *}$ & $0,31^{* *}$ & $0,60^{* *}$ & $0,49^{* *}$ & $0,58^{* *}$ & $0,66^{* *}$ & 1,00 & & & \\
\hline 8. Trust in leader & 2,94 & $0,39^{* *}$ & $0,42^{* *}$ & $0,48^{* *}$ & $0,60^{* *}$ & $0,69^{* *}$ & $0,79^{* *}$ & $0,55^{* *}$ & 1,00 & & \\
\hline 9. Trust co-worker & 4,37 & 0,10 & $0,17^{*}$ & $0,24^{* *}$ & $0,26^{* *}$ & $0,33^{* *}$ & $0,25^{* *}$ & $0,21^{* *}$ & $0,27^{* *}$ & 1,00 & \\
\hline 10. Trust manag' $\mathrm{mt}$ & 3,55 & $0,34^{* *}$ & $0,19^{*}$ & $0,39^{* *}$ & $0,49^{* *}$ & $0,55^{* *}$ & $0,51^{* *}$ & $0,47^{* *}$ & $0,55^{* *}$ & $0,39^{* *}$ & 1,00 \\
\hline
\end{tabular}

${ }^{*}$ - Signif. $\leq 0,05{ }^{* *}-$ Signif. $\leq 0,01$

TABLE 2

HIERARCHICAL REGRESSION PREDICTING THE IMPACT OF TRANSFORMATIONAL LEADERSHIP ON TRUST BEYOND THAT OF TRANSACTIONAL LEADERSHIP

\begin{tabular}{|c|c|c|c|c|c|c|}
\hline \multirow{2}{*}{$\frac{\text { Variables }}{\text { Added in Step1: }}$} & \multicolumn{2}{|c|}{ Trust in leader } & \multicolumn{2}{|c|}{ Trust in management } & \multicolumn{2}{|c|}{ Trust in colleagues } \\
\hline & Step 1 & Step 2 & Step 1 & Step 2 & Step 1 & Step 2 \\
\hline Contingent reward & $\beta 0,28^{* *}$ & $\beta 0,02$ & $\beta 0,31^{* *}$ & $\beta 0,09$ & $\beta 0,04$ & $\beta-0,11$ \\
\hline Performance mon. & $\beta 0,33^{* *}$ & $\beta 0,12^{* *}$ & $\beta 0,07$ & $\beta-0,05$ & $\beta 0,14^{+}$ & $\beta 0,06$ \\
\hline \multicolumn{7}{|l|}{ Added in Step 2: } \\
\hline Consideration & & $\beta 0,14^{+}$ & & $\beta 0,24^{*}$ & & $\beta 0,28$ * \\
\hline Demon. Trust & & $\beta 0,24^{* *}$ & & $\beta 0,16^{+}$ & & $\beta 0,02$ \\
\hline Intellect. Stim. & & $\beta-0,19$ ** & & $\beta-0,13$ & & $\beta 0,03$ \\
\hline Charisma & & $\beta 0,58^{* *}$ & & $\beta 0,16$ & & $\beta 0,00$ \\
\hline Vision & & $\beta 0,05$ & & $\beta 0,21$ * & & $\beta 0,06$ \\
\hline Adj. $R^{2}$ & 0,24 & 0,68 & 0,11 & 0,34 & 0,02 & 0,08 \\
\hline $\mathrm{F}$ & 32,95 * * & $60,95 * *$ & 11,99 * * & 14,36 ** & $2,58^{+}$ & $3,54 * *$ \\
\hline Change in unadj. $\mathrm{R}^{2}$ & & 0,44 & & 0,25 & & 0,09 \\
\hline $\mathrm{F}$ & & 54,39 ** & & 13,63 ** & & $3,85^{* *}$ \\
\hline
\end{tabular}

+ Sign $\leq 0,10 *-$ Signif. $\leq 0,05 * *-$ Signif. $\leq 0,01 \quad(1$-tailed $)$ 
positively related to trust in the leader. However, the relationships with generalized trust in others are less strong. The relationships are positive, but low for performance monitoring and contingent reward is significantly related to trust in management but not to trust in colleagues.

To assess which leadership dimensions were most relevant in predicting trust, hierarchical regression analyses were performed. In the first step, the transactional scales were entered and in the second step the transformational scales. This allows for a test of the augmentation hypothesis as proposed by Hater and Bass (1988). They hold that transformational leadership should have an effect above and beyond transactional leadership. As table 2 shows, this is indeed the case for all three trust variables. The seven leadership scales explain a total of almost $70 \%$ of the variance in trust in the leader, almost $35 \%$ of the variance in trust in management, and around $10 \%$ of the trust in co-workers. Most of this is due to the transformational scales. Interestingly, the scales which add most in the prediction vary. For instance, whereas vision does not add in the prediction of trust in the leader beyond the effects of the other scales, it is significant as a predictor for trust in management.

\section{DISCUSSION}

The current study focuses on a specific area of interpersonal trust within organizations, namely how the behavior of and relationship with one's supervisor affects trust in that supervisor as well as generalized others. In the literature, trust is assumed to be very important for transformational leadership (e.g. Bennis $\&$ Nanus, 1985). The results of this study support this notion. In line with previous research, the relationships we found between trust in the focal leader and transactional leadership dimensions are less strong than those involving transformational leadership dimensions. Similarly, as expected, the transformational leadership scales were positively related to trust in management and colleagues and these relationships were less strong for transactional leadership. In some studies faith and confidence in the leader have been measured as part of transformational leadership (e.g. Bass \& Avolio, 1990). Although the relationship between this type of leadership and trust is high, such items are measured outcomes rather than leader behavior, which supports the separation of the two. This seems especially true given the results obtained here, namely that the relationship between trust and some aspects of transformational leadership (individualized consideration, charisma) is stronger than between trust and other such aspects (intellectual stimulation, vision), even though these transformational leader behaviors were found to be highly correlated.

The major limitation of this study lies in the cross-sectional nature of the research design which prevents testing for causal relationships. Thus, although the different trust variables are treated here mostly as outcomes of leadership, the results of this study do not preclude reverse causation. For instance, trusting individuals may perceive their leader as more transformational. More research into leadership development and the nature of cause-effect relationships is necessary. One can see the relationship between transformational leadership and trust in management as a "double-edged sword" (cf. Shamir et al., 1993). When a leader's vision is in line with organizational goals and he or she is seen as representative of management, transformational leadership is likely to increase trust in management. However, when such a vision goes against organizational values or strategies, such trust in management may well decrease. In organizations, however, the latter process is constrained by selection and performance evaluation processes (certain types of people are hired and dissonant managers can be replaced or fired). Also, at lower levels in particular, leaders will often not have enough discretion or resources to pursue visions that are highly discrepant with basic organizational goals or those proposed by higher management.
The current study focused on supervisory level leadership and an interesting question is therefore whether similar relationships would be found at higher levels in the organization.

A final limitation of this study is that it is based on single source survey data. Both leader behavior and trust were measured through the eyes of subordinates using questionnaires. More research using multiple methods and sources of data is needed. The relatively high intercorrelations between the leadership scales that were found here are also commonly found in other studies using these types of questionnaires. Development of more sophisticated questionnaires or even entirely different methods to assess these types of leadership is desirable.

The results of this study seem to emphasize the importance of trust building processes in leader-follower relationships. Longitudinal research on this process is needed. The results also suggest several other interesting future studies on leadership and trust. The consequences of leaders' violations of subordinates' trust also appears to be an important area for future research. Although much research to date focuses on the positive influence leaders may have on organizational as well as individual outcomes, anecdotal evidence and popular opinion polls suggest employees are very often not happy with their supervisors and the way they are treated by them. Similarly, leaders may trust but they may also distrust their subordinates. The role of violations of trust by both leaders and followers and when these result in distrust within the dyad have not received much attention in the leadership field. However, the literature on the violation of the psychological contract and interactional justice may help theory building in this area.

The current study aimed to explore several aspects of the relationship between leadership and trust. The dynamics of trust and distrust between leaders and followers and the antecedents and consequences of such trust and distrust seem a worthwhile area for further exploration and increased insight in this area will yield both scientific insight and practical benefits.

\section{REFERENCES}

Bass, B.M. (1985). Leadership and performance beyond expectations. New York: Free Press.

Bass, B.M. (1997). Does the transactional - transformational paradigm transcend organizational and national boundaries? American Psychologist, 52 (2), 130-139.

Bass, B.M. \& Avolio, B.J. (1990). The implications of transactional and transformational leadership for individual, team, and organizational development. Research in Organizational Change and Development, 4, 231-272.

Bennis, W.G. \& Nanus, B. (1985). Leaders: The strategies for taking charge. New York: Harper Perennial.

Butler, J.K. (1991). Toward understanding and measuring conditions of trust: Evolution of a conditions of trust inventory. Journal of Management, 17, 643-663.

Butler, J.K. \& Cantrell, R.S. (1984). A behavioral decision theory approach to modeling dyadic trust in superiors and subordinates. Psychological Reports, 55, 19-28.

Clegg, C.W. \& Wall, T.D. (1981). Notes on some new scales for measuring aspects of psychological well-being. Journal of Occupational Psychology, 52, 221-228.

Cook, J.D. \& Wall, T.D. (1980). New work attitude measures of trust, organizational commitment and personal need nonfulfillment. Journal of Occupational Psychology, 53, 39-52.

Creed, W.E.D. \& Miles, R.E. (1996). Trust in organizations: A conceptual framework linking organizationalforms, managerial philosophies and the opportunity costs of controls. In R.M. Kramer \& T.R. Tyler (Eds.). Trust in organizations: Frontiers of theory and research. London: Sage.

Den Hartog, D.N. (1997). Inspirational leadership. VU doctoral dissertation. KLI-dissertation series, 1997-nr 2. Enschede: Ipskamp. 
Den Hartog, D.N., House, R.J., Hanges, P., Dorfman, P., RuizQuintanilla, A. \& 159 co-Authors. (1999). Culture specific and cross-culturally endorsed implicit leadership theories: Are attributes of charismatic/transformational leadership universal endorsed? Leadership Quarterly, 10 (2), 219-256.

Den Hartog, D.N. \& Koopman, P.L. (2001). Leadership in organizations. In N. Anderson, D.S. Ones, H. Kepir-Sinangil \& C. Viswesvaran, C (Eds.). International handbook of industrial, work and organizational psychology (Vol. 2). London: Sage.

Den Hartog, D.N., Van Muijen, J.J. \& Koopman, P.L. (1997). Transactional versus transformational leadership: An analysis of the MLQ. Journal of Occupational and Organizational Psychology, 70 (1), 19-34.

Fiol, C.M., Harris, D. \& House, R.J. (1999). Charismatic leadership: Strategies for effecting social change. Leadership Quarterly.

Fuller, J.B., Patterson, C.P., Hester, K. \& Stringer, D.Y. (1996). A quantitative review of research on charismatic leadership. Psychological Reports, 78, 271-287.

Gambetta, D (Ed.). (1988). Trust: Making and breaking cooperative relationships. New York: Basil Blackwell.

Hater, J.J. \& Bass, B.M. (1988). Superiors' evaluations and subordinates' perceptions of transformational and transactional leadership. Journal of Applied Psychology, 73, 695-702.

Hosmer, L.T. (1995). Trust: The connecting link between organizational theory and philosophical ethics. Academy of Management Review, 20, 379-403.

House, R.J. (1977). A 1976 theory of charismatic leadership. In J.G. Hunt \& L.L. Larson (Eds.). Leadership: the Cutting Edge, 189-204. Carbondale, IL: Southern Illinois University Press.

House, R.J. (1996). Path-Goal theory of leadership: Lessons, legacy and a reformulated theory. Leadership Quarterly, 7 (3), 323-352.

House, R.J., Delbecq, A. \& Taris, T.W. (1998). Value based leadership: An integrated theory and an empirical test. Submitted for publication.

House, R.J. \& Podsakoff, P.M. (1994). Leadership effectiveness: Past perspectives and future directions for research. In J. Greenberg (Ed.). Organizational behavior: The state of the science, 45-82. Hillsdale, N.J.: Erlbaum.
Howell, J.M. \& Avolio B.J. (1993). Transformational leadership, transactional leadership, locus of control and support for innovation. Journal of Applied Psychology, 78, 891-902.

Kirkpatrick, S.A. \& Locke, E.A. (1996). Direct and indirect effects of three core charismatic leadership components on performance and attitudes. Journal of Applied Psychology, 81 (1), 36-51.

Lewicki, R.J. \& Bunker, B.B. (1996). Developing and maintaining trust in work relationships. In R.M. Kramer \& T.R. Tyler (Eds.). Trust in organizations: frontiers of theory and research. London: Sage.

Lowe, K.B., Kroek, G.K. \& Sivasubramaniam, N. (1996). Effectiveness correlates of transformational and transactional leadership: A meta-analytic review. Leadership Quarterly, 7, 385-425.

Mayer, R.C., Davis, J.H. \& Schoorman, F.D. (1995). An integrative model of organizational trust. Academy of Management Review, 20, 709-734.

Podsakoff, P.M., MacKenzie, S.B., Moorman, R.H. \& Fetter, R. (1990). Transformational leader behaviors and their effects on followers' trust in leader, satisfaction and organizational citizenship behaviors. Leadership Quarterly, 1 (2), 107-142.

Podsakoff, P.M., Todor, W.D. \& Skov, R. (1982). Effects of leader contingent and noncontingent reward and punishment behaviors on subordinate performance and satisfaction. Academy of Management Journal, 25, 810-821.

Shamir, B., House, R.J. \& Arthur, M.B. (1993). The motivational effects of charismatic leadership: A self-concept based theory. Organization Science, 4, 1-17.

Shapiro, D., Sheppard, B.H. \& Cheraskin, L. (1992). Business on a handshake. Negotiation Journal, 8, 365-377.

Tichy, N.M. \& Devanna, M.A.(1990). The transformational leader (2nd ed.). New York: Wiley.

Williams, B. (1988). Formal structures and social reality. In: D. Gambetta (ed.) Trust: Making and breaking cooperative relations. New York: Basil Blackwell.

Yammarino, F.J. \& Bass, B.M. (1990). Long-term forecasting of transformational leadershipand its effects among naval officers: Some preliminary findings. In K.E. Clark \& M.B. Clark (Eds.). Measures of leadership. West Orange, NJ: Leadership Library of America. 


\section{Organisational Survey ToOls FOR Strategic Change}

We conduct surveys on the following:

- $\quad$ customer satisfaction

- $\quad$ emotional competency profile

- employee satisfaction

- communication

- $\quad$ organisational change and transformation

- $\quad$ affirmative action
- $\quad$ employee attitudes
- $\quad$ organisational culture and climate
- $\quad 360^{\circ}$ audits

- $\quad$ affirmative action

- employee attitudes

- $\quad$ employment equity and diversity

- $\quad$ training needs analysis

- $\quad 360^{\circ}$ audits

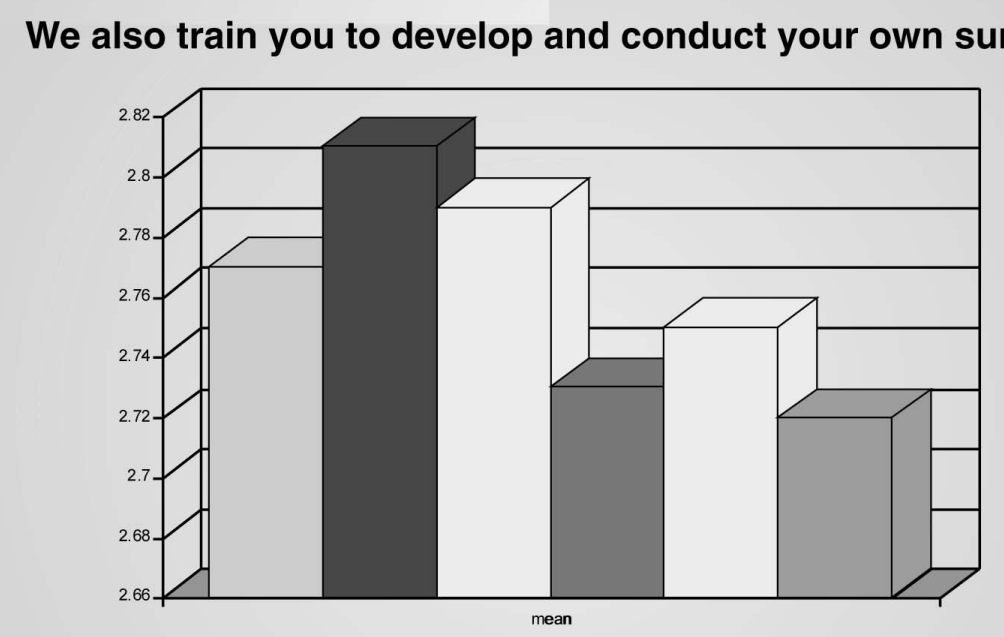

We will assist you to utilise the survey results to add value by means of:

- $\quad$ benchmarking

- $\quad$ recommending opportunities for improvement

- $\quad$ suggesting ways to improve efficiency

- $\quad$ separating facts from opinion

- $\quad$ increasing employee participation

- $\quad$ exploring opportunities for increasing profitability

We supply software packages that will allow you to continuously measure against criteria or benchmark your organisation.

Our software allows you to do surveys by means of paper, disk or e-mail / web.

"We have conducted more than 250 surveys nationally and internationally."

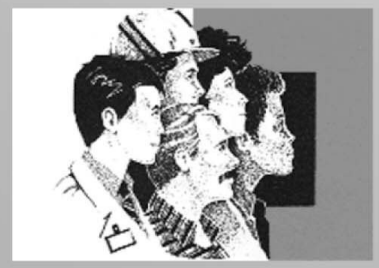

Organisational Diagnostics
Tel: 0114322006

Fax: 0114324768

E-mail: nicellen@iafrica.com Web: www.orgdia.co.za 